\title{
DOE/ER/79066--T/
}

\section{CLOSEOUT DOCUMENTATION}

GRANT NO. DE-FG05-92ER79066

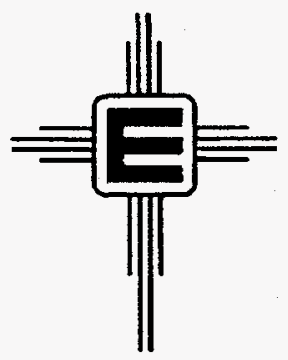

\section{Ruidoso Instructional Center}

Eastern New Mexico University

709 Mechem

Ruidoso, NM 88345

DISTAIBUTION OF THIS DOCUMENT IS UNLMMTED

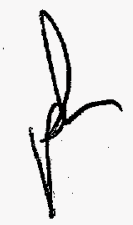

December 19, 1996 


\section{DISCLAMMER}

This report was prepared as an account of work sponsored by an agency of the United States Government. Neither the United States Government aor any agency thereof, nor any of their employees, makes any warranty, express or implied, or assumes any legal liability or responsibility for the accuracy, completeness, or usefulness of any information, apparatus, product, or process disclosed, or represents that its use would not infringe privately owned rights. Reference herein to any specific commercial product, process, or service by trade name, trademark, manufacturer, or otherwise does not necessarily constitute or imply its endorsement, recommendation, or favoring by the United States Government or any agency thereof. The views and opinions of authors expressed herein do not necessarily state or reflect those of the United States Government or.any agency thereof. 


\section{DISCLAIMER}

Portions of this document may be illegible electronic image products. Images are produced from the best available original document. 


\section{The Ruidoso Center of ENMU \\ DOE PREP Program Final Status Report - 1992}

\section{Objectives}

a. to identify, involve and retain fifty (50) students in the target audience

b. to develop interest in and awareness of career opportunities in math, science and technology ogy and in applied science careers such as medicine

c. to encourage project participants and their parents/guardians to seriously consider selection of math, science, and technical courses in middle school and high school d. to stay in school and to graduate from high school

e. to increase project participant awareness of the extensive program and financial opportunties to students to attend college and to select math, science or technical college courses and degree majors

\section{Project Accomplishments}

The project accomplished several of its short term objectives. $82 \%$ of the desired number of students completed the Summer camp and all but three participants were in the target audience. Ruidoso students within the overall group [over $50 \%$ of participants] went on to form the nucleus of the new MESA program which was initiated two months after the completion of the 1992 Summer camp. The Ruidoso Middle School MESA Coordinator has now joined the PREP project staff for the 1993 Summer camp and is tracking PREP students through Middle School. The objectives of familiarizing students with college and career opportunities were met with guest speakers from DOE facilities such as the WIPP site in Carlsbad, and at the Plant Genetics Laboratory at New Mexico State University and at the Mescalero National Fish Hatchery.

III. Project Dates: June 15 - June 25 and July 13 - July 24, 1992

IV. Student Attendance Total: $41 \quad$ 6th: $1 \quad$ 7th: $15 \quad$ 8th: 25

Female: 17 Male: 24 Native American: 4 Asian: 0 Black: 0 Hispanic 28 Caucasian: 9 Alaskan Native: 0 Pacific Islander: 0

\section{Staffing}

Team Leader: Michael Gaines, Staff: Robert Hemphill, Gina Langley, Rick Overdorf, Devra Post 


\section{U. S. Department of Energy \\ TREP \\ Attendance Summary Sheet \\ $1992-1993$}

To be filled out by the Project Director

Date: $10-26-92$

College or University:

Eastern New Mexico University

Project Director

Dr. James P. Miller, Jr.

Grant Number:

DE-FG05-92ER 79066

1. Length of Summer Program:_June 15 to June 25 and July 13 to July 24,1992

2. Total Number of Academic Year Days included: 20 (Twenty)

3. Number of Class Hours: 36 Laboratory Hours: 36 Field Trip Hours: 48

4. Number of Applicants:

47

5. Number of Participants: Summer

41 Acadernic Year:-

6. Number of Participants by Grade Level: 6th 1 7 th 8 th 25 9 th 0

$$
10 \text { th } 0
$$

7. Number of Female Participants:
17

Amercian Indian Asian 0 Black Hisparic 10 Caucasian 4 Alaskan Niative Pacific Islander 0

8. Numiber of Male Participants: $\quad 24$

Amercian Indian $\frac{1}{0}$ Asian $\frac{0}{0}$ Backan Native islander $\frac{0}{0}$ Hispanic 18 Caucasian_ 5

9. Number enrolling in science-based program in Acadernic Year 92-93 41 


\section{The Ruidoso Center of ENMU \\ DOE PREP Program Final Status Report - 1993}

\section{Objectives}

a. to identify, involve and retain fifty (50) students in the target audience

b. to develop interest in and awareness of career opportunities in math, science and technology and in applied science programs such as medicine

c. to encourage project participants and their parents/guardians to seriously consider selection of math, science, and technical courses in middle school and high school d. to stay in school and to graduate from high school

e. to increase project participant awareness of the extensive program and financial opportunities available to students to attend college and to select math, science or technical college courses and degree majors

\section{Accomplishment of Objectives}

The project accomplished several of its short term objectives. $84 \%$ of the desired number of students completed the Summer camp. Hispanic and Mescalero participation increased significantly from 1992, as well as the introduction of several new minority groups. 1992 and 1993 participants are now forming the nucleus of a new MESA project at Ruidoso High School. The objectives of familiarizing students with college and career opportunities were met with guest speakers from and/or field trips to installations such as the VLA - National Radio Astronomy Observatory, the New Mexico Natural History Museum, and Eastern New Mexico University.

III. Project Dates: June 14 - July 2 and July 12 - July 30, 1993

IV. Student Attendance Total: $42 \quad \underline{6 \text { th } 2} \quad \underline{7 \text { th } 16} \quad \underline{\text { th } 23}$

Female: 25 Male: 16 Native American: 4 Asian: $1 \quad$ Black: $0 \quad$ Hispanic 23 Caucasian: 16 Alaskan Native: 0 Pacific Islander: 0

\section{Staffing}

Team Leader: Dr. Gina Langley, Staff: Carla Burns, Frieda Dickson,, Robert Hemphill (part-time), Mickey Jacobs (college senior Chemistry student); Rick Overdorf. 


\section{U. S. Department of Energy \\ PREP \\ Attendance Summary Sheet}

To be filled out by the Project Director

Date: Aug. 25, 21993

College or University: Ruidoso Instructional Center - EMMU

Project Director:

Dr. James Mi11er Jr.

Grant Number:

DE-FG05-92ER 79066

1. Length of Summer Program: June 14 - July 2; July 12 - July 30 (4 weeks)

2. Total Number of Academic Year Days included:

0

3. Number of Class Hours:

30 Laboratory Hours: Field Trip Hours: 72

4. Number of Applicants:

41

5. Number of Participants: Summer:

41 Academic Year: 0

6. Number of Participants by Grade Level: 6 th $\quad 2 \quad 7$ th $16 \quad 8$ th $23 \quad 9$ th 10th

7. Number of Female Participants:

25

Amercian Indian Asian 0 Black 0 Hispanic 13 Caucasian 11 Alaskan Native Pacific Islander

36
Fidd Trip Hours: 72

\section{Alaskan Native}

8. Number of Male Participants: Amercian Indian Alaskan Native

$\frac{2}{0}$
Asian 0 Black_o Pacific Islander Hispanic 10 Caucasian_ 5

9. Number enrolling in science-based program in Academic Year $\underline{0}$ 


\section{The Ruidoso Center of ENMU \\ DOE PREP Program Final Status Report - 1996}

\section{Objectives}

a. to identify, involve and retain one hundred (100) students in the target audience

b. to develop interest in and awareness of career opportunities in math, science and technology and in applied science programs such as medicine

c. to encourage project participants and their parents/guardians to seriously consider selection of math, science and technical courses in middle school and high school d. to stay in school and to graduate from high school e. to increase project participant awareness of the extensive program and financial opportunities available for students to attend college and to select math, science or technical college courses and degree majors

\section{Accomplishment of Objectives}

While the project accomplished several of its short term objectives, only $53 \%$ of the desired number of students attended and completed the Summer camp. The objectives of familiarizing students with college and career opportunities were met with guest speakers at the VLA - National Radio Astronomy Observatory, the Energetic Materials Research and Testing Center (EMRTC) at New Mexico Institute of Mining and Technology, and the NSF Sunspot and Apache Point Observatories. Dr. Alan Hale, co-discoverer of the Hale-Bopp Comet, also worked with camp participants. Training in use of Powerpoint software and research on planetary astronomy via NASA web sites and the Hubble Telescope on the Internet also served to meet camp objectives.

III. Project Dates: June 10 - June 28, or July 8 - July 26, 1996

\section{Student Attendance}

Session I: Total: $25 \quad \underline{6 \text { th: } 1 \quad \text { th: } 9} \quad \underline{8 \text { th: } 13} \quad \underline{9 \text { th: } 2}$

Female: 16 Male: 9 Native American:0 Asian: 0 Black:0 Hispanic 15 Caucasian: 10 Alaskan Native: 0 Pacific Islander: 0

Session II: $\quad$ Total: $28 \quad \underline{6 \text { th: } 0} \quad \underline{7 \text { th: } 10} \quad \underline{\text { 8th: } 13} \quad \underline{9 \text { th: } 5}$

Female: 18 Male: 10 Native American :6 Asian: $0 \quad$ Black: $1 \quad$ Hispanic: 8 Caucasian: 13 Alaskan Native: 0 Pacific Islander: 0

\section{Staffing}

Team Leader: Carla Burns, Staff: Becky Austin, Frieda Dickson, Ida Maldenado, Rick Overdorf 


\section{U. S. Department of Energy \\ PREP \\ Attendance Summary Sheet}

To be filled out by the Project Director

Date:

June $10-28,1996$

College or University:

The Ruidoso Instruction Center of Eastern NM University

Project Director:

Dr. James Miller Jr.

Grant Number:

DE_RC05-92ER 79066

1. Length of Sumuner Program:

June $10-28,1996$

2. Total Number of Academic Year Days included:

0

3. Number of Class Hours: 7.5 Lathoratory Hours: 30 Fleld Trip Hours: 47

4. Number of Applicanto:

30

5. Number of Partidpants: Surnmer: Academic Year: 0

6. Number of Participants by Grade Level: 6th 1 7th 9 - 8 th 13 9th 2

10th 0

7. Numiber of Female Participants:

16

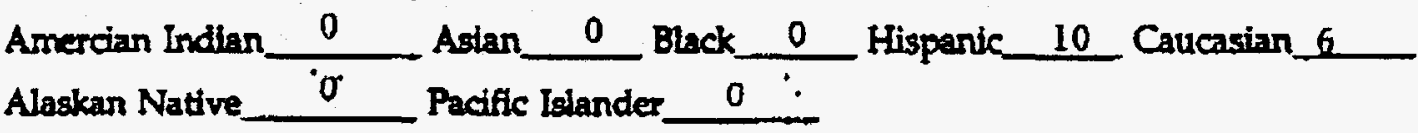

8. Number of Male Participants: 9

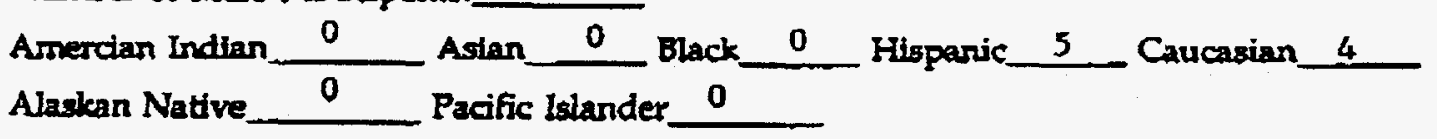

9. Number enrolling in science-based program in Acadernic Year

0 


\section{U. S. Department of Energy \\ PREP \\ Attendance Summary Sheet}

To be filled out by the Project Director

Date: July 8-26, 1996

College or University: Ruidoso Instruction Center of Eastern MM University

Project Director._Dr. Janes Miller Jr.

Grant Number:__ DB-FG05-92BR 79066

1. Length of Surmmer Program: July 8 to Ju17 26, 1996

2. Total Number of Academic Year Days included:__ 0

3. Number of Class Hours: 7.5 Laboratory Hours: 30 Field Thip Hours: 49

4. Number of Applicanta:

31

5. Number of Participante: Summer:_28_ Academic Year:

6. Number of Participants by Grade Level: 6th__ 0 7th $10 \quad 8$ th 13 9th 5

10 th

7. Number of Pemale Participants: 18 Amercian Indian $\frac{5}{0}$ Astan 0 Baskific Islander $\frac{1}{0}$ Hispanic 5 Caucasian_ 7

8. Number of Male Partidpants: Amercian Indian 1 Astar 2 Black Hispanic_ 3 Caucasian 6 Alaskan Native 0 Pacfic Islander 0

9. Number enrolling in science-based program in Academic Year 0 